\title{
Audit Tenure, Rotation and Accounting Conservatism: Empirical Evidences from Nigeria
}

\author{
Babatolu Ayorinde ${ }^{1}$, Oyewo Babajide ${ }^{2, *}$, Adewumi Ademola ${ }^{1}$ \\ ${ }^{1}$ Department of Accounting, Federal University of Agriculture, Abeokuta, Ogun State, Nigeria \\ ${ }^{2}$ Department of Accounting, University of Lagos, Akoka, Nigeria
}

Email address:

meetjidemichael@ymail.com (O. Babajide)

\section{To cite this article:}

Babatolu Ayorinde, Oyewo Babajide, Adewumi Ademola. Audit Tenure, Rotation and Accounting Conservatism: Empirical Evidences from Nigeria. International Journal of Business and Economics Research. Vol. 4, No. 6, 2015, pp. 328-336. doi: 10.11648/j.ijber.20150406.19

\begin{abstract}
Accounting regulators have, for many years, had concerns about the possible lack of Independence between auditors and their clients, which arises from a long-standing professional relationship between the two parties. The reservation stems from a widely-held belief that the risk of audit failure increases when an auditor and a client remain together for a long period of time. The possibility exists that auditors might get too familiar with their clients and in consequence loses professional scepticism and objectivity when the relationship goes on for too long. Stakeholders are therefore interested in if long-term relationship between companies and their auditors gives rise to closeness that impairs auditors' independence and reduces quality of audit work. With these in view, an attempt was made by the research to examine the link between audit tenure, rotation, and accounting conservatism using empirical data from Nigeria. Secondary data were randomly gathered by drawing 100 observations from the published financial statements of sample companies operating in the financial and nonfinancial sectors. Quantitative methods such as descriptive statistics, correlation, and multiple- regression analysis were used for data analyses. Findings were that; the tenure of auditor has a significant positive influence on firms accounting conservatism; the rotation of audit firms also significantly influences accounting conservatism. The study recommends the mandatory rotation of audit firms' lead engagement partner and the review partner on an engagement for publicly listed companies, and the strict prohibition of providing non-audit services by auditors to their clients to enhance auditors' independence and the quality of audit services.
\end{abstract}

Keywords: Audit Failure, Audit Tenure, Auditor Rotation, Conservatism, Nigeria

\section{Introduction}

History is replete with recurring instances of prominent corporate failures and collapses that have ensued in recent times, raising serious concern about the authenticity and reliability of companies' financial statements. While the preparation of an accurate financial statement is a statutory duty vested on the company directors by S.334 (1) of the companies and allied matters Act (CAMA, 2004), questions are further been put forward in respect of the quality and independence of external auditors who render assurance services. Accounting regulators have, for many years, had reservations about the independence gap that exist between auditors and their clients; this arises from a long-standing professional relationship between the two parties. Auditors working with clients for a long time would likely have increased specific knowledge about the activities of their clients, thereby increasing conservatism and result in a positive association between auditor tenure and accounting conservatism (Jenkins and Velury, 2008).

Attempts have been made by regulators to boost audit quality through formulation of rules impacting on auditors' independence. Concerns about auditors' independence were accountable in part for the development and passage of the Sarbanes Oxley Act of 2002 and the formation of the Public Company Accounting Oversight Board (PCAOB). The concern stems from a widely publicized belief that when an auditor gets too familiar with his client for a long period of time, it increases the risk of audit failure. There is every possibility that once auditors get too acquainted with their clients, they can lose professional scepticism and objectivity when such a relationship goes on for too long. It is of great interest to relevant stakeholders whether long-term relationships that exist between auditors and their client can 
bring about some level of closeness which can impair auditors' independence and reduces audit quality. To check this tendency, mandatory audit firm rotation has been suggested as a possible way out of it. The concept of mandatory auditors' rotation was introduced as a result of widely publicized corporate collapses that led to litigation. The topical issue of mandatory rotation of external auditor was perceived to be a way out of threat posed to the independence of an auditor as a result of the long relationship that may exist between the client and the auditor (Jackson et al, 2008; Myers et al, 2003; PricewaterhouseCoopers, 2002).

To ensure audit quality and investor confidence in the financial statements, a case could be made for mandatory rotation as an avenue to foster a more independent auditorclient relationship. In the mist of the scandals rocking Enron, the Comptroller General was directed by the Sarbanes-Oxley Act to study the merit and demerit of mandatory rotation. On the other hand, short term auditor-client relationships may also be associated with a high risk of audit failure due to an auditor's lack of familiarity with a client and its operations. The AICPA is of the view that new auditor-client relationships has more inherent risk, with reference to a study carried out by the SEC Practice Section, which came up with the findings that audit failures are three times more likely to occur in the case where the auditor is new to the client. Nonetheless, the Sarbanes Oxley Act requires audit partner rotation the question remains: what is the relation between audit firm tenure and audit quality?

There are two views on the issue of mandatory rotation of external auditors: one derives from the audit profession which is of the view that rotation is unnecessary because it would be costly to client and may reduce the quality of audits. The second perspective is from the regulators, which is in support of the rotation of the external auditors requiring audit firm to periodically let go of their client because of the notion that it could solve the problem of independence. It is against this background that the research attempts to empirically examine audit tenure, rotation and accounting conservatism using empirical data from Nigeria.

\section{Review of Related Literature}

Conservatism has been seen as an integral part of accounting practice, which is usually expressed as the anticipation of losses and the non-recognition of profit (Bliss 1924). Anticipating profits could be seen as recording profits before there is legal claim to their associated future cash flows and before the revenues are verifiable (Watts 2003). Financial Accounting Standards Boards (FASB) Statement of Concepts No.2 justifies this behaviour by defining conservatism as "a prudent reaction to uncertainty to try to ensure that uncertainties and risks inherent in business situations are satisfactorily considered" (FASB 1980:36). Many construe this as traditional guidance for choosing between various methods of accounting for similar transactions. Conservatism suggests that when accountants are to make professional judgements and there is insufficient evidence as to information taking a position, the position to be taken should be the one which will less likely lead to overstatement of assets and income. Basu (1997) viewed conservatism as representing the accountant's predisposition to involve a high sense of authentication to see good news as gains than to see bad news as losses. In other words, conservatism can be defined as accountants' asymmetric acknowledgment of unrealized gains and losses in reported earnings. Building on this interpretation, Basu (1997) posits that accountants spot bad news in earnings more promptly than good news. Thus, if we are of the opinion that current equity returns efficiently put together good and bad news regarding firms' expected future cash flows, we expect that the slope coefficient and $R 2$ in a regression of earnings on unexpected returns should be higher for firms with negative unexpected returns (proxy for "bad news") and lower for those with positive unexpected returns (proxy for "good news"). The empirical results from Basu (1997) are consistent with this prediction. Basu's measures have been used in so many studies to assess the degree of accounting conservatism (Givoly and Hayn, 2000, Ball et al. 2000, 2003, Chaney and Philipich 2003, Krishnan 2003a, Francis et al. 2004, etc.).

The importance of accounting conservatism principle in accounting practice cannot be over emphasized, as it is essential to understand the variance, and the inherent link between the traditional concept of accounting conservatism and the unevenness of recognition presented by Basu (1997). Going by how recent the literature is, the concept of conservatism was inconsistent across studies. The traditional conservatism is called ex ante conservatism (Giner and Rees, 2001; Pope and Walker, 2002; Richardson and Tinaikar, 2004), news independent conservatism (Chandra et al., 2004) or unconditional conservatism (Ball and Shivakumar, 2006; Beaver and Ryan, 2005; Ryan and Zarowin, 2003). Basu's concept of conservatism was referred to as ex post conservatism (Richardson and Tinaikar 2004), newsdependent conservatism (Chandra et al. 2004), or conditional conservatism (Beaver and Ryan 2005, Ball and Shivakumar 2005, 2006). For the purpose of discussion, we will use the concept of unconditional and conditional conservatism throughout this study. Unconditional conservatism arose from policies that reduce earnings free of current economic news or from the application of generally accepted accounting principles (GAAP), denoting that aspects of the accounting process determined at the time of acquisition of assets and liabilities yield expected undervalued assets. Prompt expensing of the costs of most internally developed intangibles, accelerated depreciation of property, plant, and equipment, and historical cost accounting for positive net present value projects are examples of unconditional conservatism. As noted in Basu (1997), since unconditional conservatism is independent of current-period news, it will lower the intercept in a regression of earnings on returns but will not affect the slope coefficient. That is, the implementation of unconditional conservatism will not have an impact on the relation between earnings and returns in the 
current period.

On the other hand, conditional conservatism implies that bad news is recognised asymmetrically compared to good news: which means that, book values are written down under unfavourable circumstances but not written up under favourable circumstances. Examples of conditional conservatism include, the market accounting rule for inventory, impairment accounting for long-lived tangible and intangible assets, and the asymmetric recognition of contingent losses and contingent gains. Thus, in an efficient market situation if good news and bad news are arrested promptly and totally in equity prices, the use of conditional conservatism will snowball to the slope coefficient in the regression of earnings on current returns being higher for firms with negative unexpected returns (proxy for bad news) than for those with positive unexpected returns (proxy for good news).

Only recently have researchers begun to study the interaction between the two types of conservatism. For example, Basu (2001) notes that less conservative newsunrelated accounting allocation methods are more likely to result in asset write downs, and hence, greater asymmetric news-driven conservatism. DeAngelo (1981) argued that audit firm size could be a surrogate of audit quality. Thus, big audit firms are expected to provide high quality earnings in financial statements. Consistent with this argument, Basu (2001) demonstrated that the earnings reported by big auditees are more conservative than the earnings of non-big auditees. Earnings conservatism can be used by audit firms as a risk management strategy. Audit firms can maintain higher reported audit quality by demanding more conservative earnings for their clients even under the 'threat' of auditor independence.

To critically examine the relationship between audit firm tenure, audit firm rotation and conservatism as an intrinsic attribute of earnings quality, an in-depth understanding of earnings quality is essential. Most of the studies opined that, the quality of financial reporting depends on the company's management and the audit firm since financial statements are perceived as a joint product of the duo (Antle and Nalebuff, 1991; Hamilton et al., 2005). Supposing that auditor independence has a directly effect on the quality of an audit, this will imply that any such change in auditor independence will translate to a change in the quality of the financial statements, hence affects the quality of reported earnings. Proponents of auditor rotation are of this argument that auditors would provide more support for aggressive accounting by the client's management when their independence is compromised, which in due course result in failures to spot material errors (Myers et al., 2003). Further, when the auditor-client relationship lengthens, management is likely to gain more reporting flexibility which could result in earnings management quality (Davis et al., 2000). Hamilton et al. (2005) opined that utmost criticism with respect to reduced auditor independence and its effect on earnings quality "seems to be premised on instances of overly aggressive reporting, whereby the underlying deterioration in the profitability of collapsing firms has been concealed". Aggressive reporting has been defined as using reporting methods that portray "the client's financial situation favourably when that method is not clearly indicated by the facts and relevant professional literature". The methods in totality are likely to result in an increase of earnings and/or liquidity in the sense that managers have incentives to partially estimate the future values in favour of current earnings (Basu, 1997).

The relationship between a long audit-client relationship and audit quality is not farfetched because economic, financial and social factors could drive the final result. Most empirical studies define audit quality relative to risk which is the risk that an auditor will fail to modify the opinion on audited financial statement that are materially misstated. If auditors are more independent, there is the likelihood that they will not compromise their integrity by attempting to manipulate earnings management, which would be shown in more income decreasing items being recorded (Kaplan and Mauldin, 2008). Given that audit firm rotation impacts the independence of the auditor and also impact aggressive reporting, a variation in earnings depicting losses on a timely basis than gains would exist after audit firm rotation. Francis et al. (2004) argued that conservative accounting results in higher accounting quality. This research takes the position that the level of earnings conservatism in reported earnings can be used to identify changes in the quality of those earnings after audit firm rotation.

\section{Research Method}

\subsection{Population and Sample of Study}

The population of the study consists of all quoted firms in Nigerian Stock Exchange. Samples were drawn from these sectors using the NSE classification of publicly quoted companies: Agriculture, Automobile \& Tyre, Breweries, Building Materials, Chemical and Paints, Conglomerates companies, Food/Beverages \& Tobacco, Construction, Healthcare, Industrial/Domestic Products, Packaging, Printing \& Publishing, Textiles, Petroleum marketing companies, Banking, Insurance and others. 30 companies covering these sectors were randomly selected using the published financial statements for two years -2009 and 2010. On the whole, 100 observations comprising of 50 from the financial sector and 50 from the non-financial sector were used.

\subsection{Research Hypotheses and Model Specification}

The purpose of the present study was to investigate association between accounting conservatism (financial report quality) and audit tenure and rotation in Nigeria.

The following hypotheses have been formulated and expressed in the alternative form for the study:

$\mathrm{H}_{1}{ }_{1}$ : The tenure of auditor exert a positive influence on the firm's accounting conservatism.

$\mathrm{H}_{1}^{2}$ : The rotation of a firm's auditor exerts positive influence on its accounting conservatism. 
$\mathrm{H}_{1}{ }^{3}$ : Firm's accounting conservatism is positively associated with the rotation of audit partner.

The model adopted for the study started with a focus on measuring accounting conservatism (financial report quality) using total accruals, which were then partitioned into discretionary and non-discretionary accruals. Chen et al (2007) opined that the absolute discretionary accruals (ADA) which is a more popular and widely use indicator for measuring mangers accounting estimates and accounting choices. Thus, discretionary accrual was used to proxy accounting conservatism. In establishing discretionary accruals, we used the modified Jones model. Beaver and Ryan (2005) identified the Jones model as a strong tool for measuring accounting conservatism (discretionary accruals). Dabor and Adeyemi (2009) identified that the model uses components of annual financial statements such as turnover (Sales revenue), account receivables, profit and assets to establish discretionary accruals. Added to the above, the model establishes total accruals by subtracting cash flow from operations from net income before extraordinary items. Thus,

$$
\mathrm{TACC}=\mathrm{EBEI}-\mathrm{CFO}
$$

Where TACC represents total accruals, EBEI is the net income before extraordinary items, and CFO is cash flow from operations. Total accruals are then partitioned into two components i. e non-discretionary accruals, which relate to normal activities of the company and discretionary accruals, which are determined according to the subjective reasoning of management. That is, discretionary accrual is a function of accounting conservatism (management choice of accounting policies).

$$
\text { TACC }=\alpha_{0}+\alpha_{1}(\Delta \mathrm{REV}-\Delta \mathrm{REC})+\alpha_{2} \mathrm{PPE}+\alpha_{3} \mathrm{ROA}_{\mathrm{t}-1}+\mathrm{e}
$$

Where $\triangle \mathrm{REV}$ is change in revenue; $\triangle \mathrm{REC}$ is change in accounts receivable; PPE means plants, property and equipment (Fixed Assets) and ROA is return on assets managed in the previous accounting period. All the variables that enter the equation are scaled by total assets (TA) of the previous year- $\mathrm{TA}_{\mathrm{t}-1}$.

The non-discretionary accruals portion (NDA) is also modelled as a function of the change in revenue, change in accounts receivable, plants, property and equipment and return on assets in the previous accounting period as follows;

$$
\mathrm{NDA}=\alpha_{0}+\alpha_{1}(\Delta \mathrm{REV}-\Delta \mathrm{REC})+\alpha_{2} \mathrm{PPE}+\alpha_{3} \mathrm{ROA}_{\mathrm{t}-1}
$$

The difference between (2) and (3) above is the residual e, and this is the discretionary accruals (DA). Thus,

$$
\mathrm{DA}=\mathrm{TACC}-\left[\alpha_{0}+\alpha_{1}(\Delta \mathrm{REV}-\Delta \mathrm{REC})+\alpha_{2} \mathrm{PPE}+\alpha_{3} \mathrm{ROA}_{\mathrm{t}-1)}\right]
$$

All the variables, except $\mathrm{ROA}_{\mathrm{t}-1}$, are scaled by total assets in previous year.

In the light of the above and the research hypotheses we specified a multiple regression econometric model (4). By definition, multiple regression econometric models is one that seeks to explain change or variation in the values of one variable called the dependent variable (accounting conservatism) on the basis of changes in other variables known as the independent or explanatory variables (audit firm rotation and audit partner rotation). The assumption is that the dependent variable is a linear function of the independent variables. The function form of the model is express as follows;

$$
\mathrm{ACC}=\mathrm{f}(\text { AUTEN, AUDROT, AUDPAT })
$$

The multiple regression with an error term $\left(\mathcal{E}_{t}\right)$ is express in equation (6)

$$
\mathrm{ACC}=\alpha_{0}+\beta_{1} \mathrm{AUTEN}+\beta_{2} \mathrm{AUDROT}+\beta_{3} \mathrm{AUDPAT}+\varepsilon_{t}
$$

\begin{tabular}{|c|c|c|}
\hline Variables & $\begin{array}{l}\text { Apriori } \\
\text { Sign } \\
\end{array}$ & Explanation \\
\hline $\mathrm{ACC}$ & & $\begin{array}{l}\text { Accounting conservatism is measured as } \\
\text { discretionary accruals (DA); DA }=\text { TACC }-\left[\alpha_{0}\right. \\
+\alpha_{1}(\Delta \mathrm{REV}-\Delta \mathrm{REC})+\alpha_{2} \mathrm{PPE}+\alpha_{3} \mathrm{ROA}_{\mathrm{t}-1)}\end{array}$ \\
\hline AUTEN & $+/-$ & $\begin{array}{l}\text { Auditor Tenure (number of years the current } \\
\text { auditor has been firms). The following code } \\
\text { was used to measure firms auditor tenure; we } \\
\text { assign the values of " } 1 \text { " for Less than one year, } \\
\text { "2" for more than one years but less than 3yeras } \\
\text { and " } 3 \text { " for more three years. }\end{array}$ \\
\hline AUDROT & & $\begin{array}{l}\text { Firms Auditor rotation. We use three dummy to } \\
\text { proxy firms type of auditor rotation. These } \\
\text { three dummy are express as follows; } \\
\text { (i)AUDROTD1 = is assign the value of " } 1 \text { " } \\
\text { when there is a change of auditor from non-big } \\
4 \text { to Big } 4 \text { (CROSS UP) otherwise " } 0 \text { " } \\
\text { (ii)AUDROTD2 = is assign the value of " } 1 \text { " } \\
\text { when there is a change of auditor from big } 4 \text { to } \\
\text { non-Big } 4 \text { (CROSS DOWN) otherwise " } 0 \text { " } \\
\text { (iii)AUDROTD } 3 \text { = is assign the value of " } 1 \text { " } \\
\text { when there is a change of auditor from big } 4 \text { to } \\
\text { another Big } 4 \text { (LATERAL) otherwise " } 0 \text { " }\end{array}$ \\
\hline AUDPAT & & $\begin{array}{l}\text { Firms Auditor partner rotation. The value of } \\
\text { " } 1 \text { " is assign when there is a change of firms } \\
\text { auditor partner, otherwise " } 0 \text { " }\end{array}$ \\
\hline
\end{tabular}

Table 1 provides a summary of variable definitions and expected signs for relations.

Table 1. Definition of Variables and Expected Signs.

The study used Descriptive Statistics, Correlation Analysis, and multiple Ordinary Least Square (OLS) Regression Analysis. The model was estimated using the ordinary least square (OLS) estimation technique with the aid of computer software (Eviews 7). The hypotheses stated was tested using the t-ratios obtained from the regression result. To ensure that our model is statistical and econometrically valid we conducted diagnostic test such as goodness fit and heteroscedaticity test.

\section{Data Presentation and Analysis}

\subsection{Descriptive Statistical Analysis}

The descriptive statistical analysis result of variables is captured in table 2 . Result shows that the minimum audit tenure of firms quoted on the Stock Exchange is about a year 
while the maximum audit tenure is about 5 years. On average the audit tenure is about 4.5 years. 63 firms have had the same auditor from 2006 to 2010 which indicates No audit rotation. Hence majority of firms quoted on the Stock exchange do not rotate their auditors.

Table 2. Descriptive statistics of study variables.

\begin{tabular}{|c|c|c|c|c|c|}
\hline & TENURE & AUDROTD1 & AUDROTD2 & AUDROTD3 & $\mathrm{ACC}$ \\
\hline Mean & 4.5 & 0.02 & 0.02 & 0.55 & 97381941 \\
\hline Median & 5 & 0 & 0 & 1 & 3925558 \\
\hline Maximum & 5 & 1 & 1 & 1 & $3.36 \mathrm{E}+09$ \\
\hline Minimum & 1 & 0 & 0 & 0 & -9072908 \\
\hline Std. Dev. & 1.267304 & 0.140705 & 0.140705 & 0.5 & $4.04 \mathrm{E}+08$ \\
\hline Skewness & -2.319302 & 6.857143 & 6.857143 & -0.201008 & 6.737039 \\
\hline Kurtosis & 6.57114 & 48.02041 & 48.02041 & 1.040404 & 50.39974 \\
\hline Jarque-Bera & 142.7904 & 9228.828 & 9228.828 & 16.67347 & 10117.86 \\
\hline Probability & 0 & 0 & 0 & 0.00024 & 0 \\
\hline Observations & 100 & 100 & 100 & 100 & 100 \\
\hline
\end{tabular}

The minimum auditor rotation from non-big4 to big4 (AUDROTD1) is 0 while the maximum auditor rotation from non-big4 to big4 (AUDROTD1). It was observed that only one firm had changed from non-big4 to big4 audit firm. The minimum auditor rotation from big4 to non-big4 (AUDROTD2) is 0 while the maximum auditor rotation from big4 to non-big4 (AUDROTD2). It was observed that only three firms had changed from big4 to non-big4 audit firm. The minimum auditor rotation from big4 to big4 (AUDROTD3) is 0 while the maximum auditor rotation from big4 to big4 (AUDROTD3). It was observed that only six firms had changed from big4 to non-big4 audit firm. The jarque-Bera statistics revealed that all the variables are normally distributed.

\subsection{Inferential Statistical Analysis}

\subsubsection{Correlation Analysis}

In exploring the relationship between accounting conservatism and the variables used in the study, we carried out correlation analysis using Pearson product moment correlation method. The results are presented in the table 3.

Table 3. Correlation analysis between Audit Tenure, Rotation, and Accounting conservatism.

\begin{tabular}{llllll}
\hline & TENURE & AUDROTD1 & AUDROTD2 & AUDROTD3 & ACC \\
\hline TENURE & 1 & -0.056647 & -0.113293 & -0.231144 & -0.051144 \\
AUDROTD1 & -0.05665 & 1 & 0.489796 & -0.345209 & -0.014358 \\
AUDROTD2 & -0.11329 & 0.489796 & 1 & -0.345009 & -0.043303 \\
AUDROTD3 & -0.23114 & -0.014358 & -0.014358 & -0.043303 \\
ACC & 0.051144 & -0.345209 & -0.345009 & 1 \\
\hline
\end{tabular}

There is a weak positive relationship of about $5 \%$ between accounting conservatism and audit tenure. An increase in audit tenure would lead to an increase in accounting conservatism. There is fairly weak negative relationship between accounting conservatism and auditor rotation from non-big4 to big4 (AUDROTD1) with correlation co-efficient of -0.35). With a correlation co-efficient of -0.35 , the relationship between accounting conservatism and auditor rotation from big4 to non-big4 (AUDROTD2) is fairly weak and negative. There exists a weak negative relationship between accounting conservatism and auditor rotation from big4 to big4 (AUDROTD3) with a correlation value of 0.04 .

An increase in auditor rotation from non-big4 to big4 audit firm, rotation from big4 to non-big4, or rotation from big4 to big4 should lead to a decrease in accounting conservatism.

\subsubsection{Regression Analysis}

Regression Analysis for 2009.

The result from the ordinary least square regression result is presented in table 4 .

Table 4. Ordinary Least Square regression result for 2009.

\begin{tabular}{lllc}
\hline Variable & Coefficient & Std. Error & t-Statistic \\
\hline C & $-1.20 \mathrm{E}+08$ & $1.59 \mathrm{E}+08$ & -0.755601 \\
TENURE & -34855898 & 30746418 & -2.133657 \\
AUDROTD1 & $-6.67 \mathrm{E}+08$ & $3.07 \mathrm{E}+08$ & -2.175414 \\
AUDROTD2 & $-7.01 \mathrm{E}+08$ & $3.08 \mathrm{E}+08$ & -2.273202 \\
AUDROTD3 & 60897974 & 77439048 & 0.0348 \\
R-squared & 0.373564 & Mean dependent var & 0.786399 \\
Adjusted R-squared & 0.338767 & S. D. dependent var & 0.0253 \\
S. E. of regression & $3.74 \mathrm{E}+08$ & Akaike info criterion & 97381941 \\
Sum squared resid & $1.33 \mathrm{E}+19$ & Schwarz criterion & $4.04 \mathrm{E}+08$ \\
Log likelihood & -2113.433 & F-statistic & 42.36866 \\
Durbin-Watson stat & 1.995234 & Prob (F-statistic) & 42.49892 \\
\hline
\end{tabular}


The coefficient of determination (R-Square) with a value of 0.37 means that about $37 \%$ of the total systematic variations in accounting conservatism (ACC), have been explained by the explanatory variables taken together. The Adjusted R-square shows that even after adjusting for the degree of freedom the model could still explain only about $33 \%$ of the total systematic variations in accounting conservatism (ACC) while about $67 \%$ of the systematic variation in accounting conservatism (ACC) was left unaccounted for by the model which has been captured by the stochastic disturbance term in the model. This implies that other factors apart from audit tenure and audit rotation affect accounting conservatism in Nigeria.

It was observed that the overall model was statistically significant since the calculated $\mathrm{F}$ - value of 4.92 was greater than the critical F-value at 5\% level of significance. On the basis of the individual statistical significance, as shown by the t-ratios in the table above, it was observed that TENURE, AUDROTD1, and AUDROTD2 was statistically significant since their calculated t-values of $2.13,2.17$ and 2.27 respectively was greater than the critical t-value of 2.0 at $5 \%$ level of significance under the two tailed test. This means that TENURE, AUDROTD1, and AUDROTD2 had a significant impact on accounting conservatism while AUDROTD3 was not statistically significant since the calculated t-value of 0.78 was less than the critical t-value of 2.0 at $5 \%$ level of significance under the two tailed test.

The Durbin Watson statistics of 1.99 indicates the absence of first order autocorrelation of the stochastic variables inside the error term in the model.

Regression Analysis for 2010.

Table 5. Ordinary Least Square regression result for 2010.

\begin{tabular}{lllll}
\hline Variable & Coefficient & Std. Error & t-Statistic & Prob. \\
\hline C & $2.58 \mathrm{E}+08$ & 69471395 & 3.710957 & 0.0004 \\
TENURE & -44327552 & 13643305 & -3.249033 & 0.0016 \\
AUDROTD1 & $-1.32 \mathrm{E}+08$ & 71225337 & -1.857552 & 0.0664 \\
AUDROTD2 & $-1.24 \mathrm{E}+08$ & 61118635 & -2.024279 & 0.0458 \\
AUDROTD3 & 43474567 & 44423766 & 0.978633 & 0.3303 \\
AR (1) & 0.375306 & 0.098735 & 3.801141 & 0.0003 \\
R-squared & 0.247020 & Mean dependent var & 43414285 \\
Adjusted R-squared & 0.206097 & S. D. dependent var & $1.04 \mathrm{E}+08$ \\
S. E. of regression & 92313259 & Akaike info criterion & 39.57854 \\
Sum squared resid & $7.84 \mathrm{E}+17$ & Schwarz criterion & 39.73681 \\
Log likelihood & -1933.349 & F-statistic & 6.036233 \\
Durbin-Watson stat & 2.166138 & Prob (F-statistic) & 0.000071 \\
\hline
\end{tabular}

The coefficient of determination (R-Square) with a value of 0.24 means that about $24 \%$ of the total systematic variations in accounting conservatism (ACC), have been explained by the explanatory variables taken together. The Adjusted R-square shows that even after adjusting for the degree of freedom the model could still explain only about $20 \%$ of the total systematic variations in accounting conservatism (ACC) while about $80 \%$ of the systematic variation in accounting conservatism (ACC) was left unaccounted for by the model. Overall, the model was statistically significant since the calculated F- value of 6.03 was greater than the critical F- value at $5 \%$ level of significance.

On the basis of the individual statistical significance, as shown by the t-ratios in the table above, it was observed that TENURE, AUDROTD1, and AUDROTD2 was statistically significant since their calculated t-values of 3.2, 1.85 and 2.02 respectively was greater than the critical t-value at $5 \%$ and $10 \%$ level of significance under the two tailed test. This means that TENURE, AUDROTD1, and AUDROTD2 had a significant impact on accounting conservatism while AUDROTD3 was not statistically significant since the calculated t-value of 0.97 was less than the critical t-value at $5 \%$ and $10 \%$ level of significance under the two tailed test. Thus, audit rotation from big4 to big4 audit firm has no significant impact on accounting conservatism. Furthermore, it was observed that TENURE, AUDROTD1, and AUDROTD2 had a negative relationship with accounting conservatism while AUDROTD1 had a positive relationship with accounting conservatism. The Durbin Watson statistics of 2.16 indicates the absence of first order autocorrelation of the stochastic variables inside the error term in the model.

\subsubsection{Pooled Regression Analysis}

Table 6. Pooled Ordinary Least Square regression result.

\begin{tabular}{lllll}
\hline Variable & Coefficient & Std. Error & t-Statistic & Prob. \\
\hline C & $1.90 \mathrm{E}+08$ & 95851995 & 1.984407 & 0.0487 \\
TENURE & -33668373 & 19164255 & -1.756832 & 0.0806 \\
AUDROTD1 & $-3.17 \mathrm{E}+08$ & 98391253 & -3.224391 & 0.0015 \\
AUDROTD2 & -55068027 & 83607088 & -2.658653 & 0.0309 \\
AUDROTD3 & -22252045 & 62997046 & -0.353224 & 0.7243 \\
AR (1) & 0.062273 & 0.073264 & 0.849981 & 0.3964 \\
R-squared & 0.119767 & Mean dependent var & 35373807 \\
Adjusted R-squared & 0.096105 & S. D. dependent var & $1.80 \mathrm{E}+08$ \\
S. E. of regression & $1.71 \mathrm{E}+08$ & Akaike info criterion & 40.78292 \\
Sum squared resid & $5.44 \mathrm{E}+18$ & Schwarz criterion & 40.88471 \\
Log likelihood & -3909.160 & F-statistic & 5.061543 \\
Durbin-Watson stat & 2.037436 & Prob (F-statistic) & 0.000225 \\
\hline
\end{tabular}

The coefficient of determination (R-Square) with a value of 0.119 means that about $12 \%$ of the total systematic variations in accounting conservatism (ACC), have been explained by the explanatory variables taken together. The Adjusted R-square shows that even after adjusting for the degree of freedom the model could still explain only about $10 \%$ of the total systematic variations in accounting conservatism (ACC) while about $90 \%$ of the systematic variation in accounting conservatism (ACC) was left unaccounted for by the model which has been captured by the stochastic disturbance term in the model. This implies that other factors apart from audit tenure and audit rotation affect accounting conservatism in Nigeria.

The F-statistics shows that the overall model was statistically significant since the calculated F- value of 5.06 was greater than the critical F-value at 5\% level of significance. it was observed that TENURE, AUDROTD1, and AUDROTD2 was statistically significant since their calculated t-values of $1.75,3.22$ and 2.65 respectively was greater than the critical t-value at $5 \%$ and $10 \%$ level of significance under the two tailed test.

Thus, audit rotation from big4 to big4 audit firm has no 
significant impact on accounting conservatism. Furthermore, it was observed that TENURE, AUDROTD1, AUDROTD2 and AUDROTD1 had a negative relationship with accounting conservatism. Durbin Watson statistics of 2.0 indicates the absence of first order autocorrelation of the stochastic variables inside the error term in the model.

\subsection{Hypotheses Testing}

Hypothesis 1

$\mathrm{H}_{1}^{1}$ : The tenure of auditor exert a positive influence on the firm's accounting conservatism

The empirical result reveals that TENURE with a calculated t-value of 1.75 is greater than the critical t-values of 1.64 at $10 \%$ level of significance under the two-tailed test. Hence, we reject the null hypothesis and accept the alternative hypothesis that the tenure of auditor exerts a significant influence on firms accounting conservatism.

Hypothesis 2

$\mathrm{H}_{1}^{2}$ : The rotation of a firm's auditor exerts positive influence on its accounting conservatism

The empirical result reveals that AUDROTD1 with a calculated t-value of 3.22 is greater than the critical t-values of 1.64 at $10 \%$ level of significance under the two-tailed test. Hence, we reject the null hypothesis and accept the alternative hypothesis that the rotation of audit firms from Big 4 to Non-Big4 audit firms exerts a significant influence on firms accounting conservatism.

Hypothesis 3

$\mathrm{H}_{1}^{3}$ : Firm's accounting conservatism is positively associated with the rotation of audit partner.

The empirical result reveals that AUDROTD2 with a calculated t-value of 2.65 is greater than the critical t-values of 1.64 at $10 \%$ level of significance under the two-tailed test. Hence, we reject the null hypothesis and accept the alternative hypothesis that the rotation of audit firms from Non-Big 4 to Big4 audit firms exerts a significant influence on firms accounting conservatism.

\section{Discussion of Findings}

The study revealed that the tenure of auditor has a significant positive influence on firms accounting conservatism; conservatism increases as auditor tenure lengthens. This is consistent with the findings of Jenkins and Velury (2008) that conservatism increases as auditor tenure lengthens. The study also showed that the rotation of audit firms from Non-Big 4 to Big4 audit firms and from Big 4 to Non- Big4 audit firms has a significant influence on accounting conservatism which is in tandem with the findings of Sinnett (2004) that mandatory auditor rotation will adversely affect not only the auditors' accumulation of specific knowledge about their clients, but also auditors' independence because it undermines the incentives to build up a reputation for auditors' honesty, especially in the last period before rotation. Meanwhile, a newly appointed auditor might fail because of lack of a thorough understanding of the client. Incumbent auditors can profit from their learning curve effect in the detection of material errors or breach.

The study establishes the necessity to have properly defined maximum legal audit tenure, in order to minimize audit tenure elongation in Nigeria. There has been recent expression of concern by the Institute of Chartered Accountants of Nigeria, ICAN, that a long involvement of an individual or audit team with a client could lead to circumstances that could threaten objectivity and independence. It therefore suggested an orderly rotation of senior personnel serving on an audit engagement (section 4:76 of Rules of Professional Conduct for Members).

The study found out that long audit tenure impacts negatively on the quality of the auditor's report when the audit tenure is prolonged. This indicates that the longer the audit tenure, the lower the quality of audit. This disagrees with the findings of Ghosh and Moon (2005), Carcello and Nagy (2004) that prolongation of audit tenure increases audit quality because an auditor is able to gain firm-specific expertise and a better understanding of the client's business as the auditor's tenure. The study revealed that audit rotation can minimize the negative impact of long tenure, but the audit firms rather than audit partners should be rotated.

\section{Conclusion and Recommendations}

The study has attempted to empirically examine audit tenure, rotation and accounting conservatism in Nigeria. We therefore conclude that: the tenure of auditor has a significant influence on firms accounting conservatism; the rotation of audit firms from non-big4 to big4, rotation from big4 to nonbig4, or rotation from big4 to big4 has a significant influence on accounting conservatism. In Nigeria, there exists a negative relationship between audit tenure and audit quality. This indicates that the longer the audit tenure, it may create familiarity threat by virtue of a close relationship with the client, its directors, officers or employees. The audit opinion of the auditor will favour the client, thus, impairing the independence of the auditor. Low-quality audits can mislead investors and result in misallocated resources. To ensure quality of audit and enhance auditor's independence, a period of five years has been suggested and adopted in some countries as the maximum audit tenure in an auditee company for a principal partner of a firm.

The research contributes to knowledge in that it scientifically examines the connection between audit tenure, rotation and accounting conservatism. It also empirically established that the tenure.

The study recommends the mandatory rotation of audit firm lead engagement partner and the review partner on an engagement for publicly listed companies. A partner rotated after a pre-defined period should not resume the lead engagement role until a further period of time, say minimum of two years. The tenure of the Appointed Auditor should be one year in the first instance, renewable annually subject to satisfactory performance for 3 years and on no account should annual renewal extend the total tenure of the appointed firm or firms beyond 5 years. This is to ensure that 
the independence of the auditor is not placed in jeopardy. Professional bodies such as the Institute of Chartered Accountants of Nigeria (ICAN) should strictly ensure that their members who audit for their clients do not audit for more than three years at a stretch to preserve the independence of the auditor and his objectivity. There should be strict prohibition as to the provision of non-audit services by auditors to their audit clients. This could impair an auditor's independence. The auditor would lack independence if he represents an audit client before a law court on matters outside their main audit job such as maintaining or preparing the audit client's accounting records, preparing financial statements and originating source data underlying the audit client's financial statements.

\section{References}

[1] Antle, R., and Nalebuff, B. (1991). Conservatism and auditorclient negotiations. Journal of Accounting Research, 29: 3154 .

[2] Ball, R. and Shivakumar, L. (2005). Earnings quality in UK private firms: comparative loss recognition timeliness. Journal of Accounting and Economics 39 (1): 83-128.

[3] Ball, R. and Shivakumar, L. (2006). The Role of Accruals in Asymmetrically Timely Gain and Loss Recognition. Journal of Accounting Research 44 (2): 207-242.

[4] Ball, R., Kothari, S. and Robin, A. (2000). The Effect of International Institutional Factors on Properties of Accounting Earnings. Journal of Accounting and Economics 29 (1): 1-51.

[5] Basu, S. (1997). The conservatism principle and the asymmetric timeliness of earnings, Journal of Accounting and Economics 24 (1): 3-37.

[6] Basu, S. (2001). Discussion of 'on the asymmetric recognition of good and bad news in France, Germany and the United Kingdom'. Journal of Business Finance \&Accounting 28 (910): 1333-1349.

[7] Beaver, W. and Ryan, S. (2005). Conditional and unconditional conservatism: concepts and modelling. Review of Accounting Studies 10 (2-3): 269-309.

[8] Bliss, J. (1924). Management through accounts. New York: Ronald Press.

[9] Carcello, J. and A. Nagy (2004). Audit firm tenure and fraudulent financial reporting Auditing: A Journal of Practice and Theory 23 (2): 55-69.

[10] Chandra, U., Wasley, C. and Waymire, G. (2004). Income conservatism in the U.S. technology sector. Working paper, University of Rochester.

[11] Chaney, P. and Philipich, K. (2003). The price-earnings relation in troubled times: the case of Arthur Andersen. Working paper, Vanderbilt University and The Ohio State University.

[12] Chen, K., Elder, R. and Hsieh, Y. (2007). Corporate Governance and Earnings management: The Implication of Corporate Governance Best Practice Principles for Taiwanese listed companies, Working paper series (Retrieved from www.ssrn.com).
[13] Companies and Allied Matters Act (CAMA) 2004.

[14] Dabor, E. and Adeyemi, S. (2009). Corporate Governance and the Credibility of Financial Statements in Nigeria. Journal of Business System, Governance and Ethics, 4 (1); 13-24.

[15] Davis, L. R., Soo, B., and Trompeter, G. (2000). Auditor tenure, auditor independence and earnings management. Working paper, Michigan Tech University and Boston College.

[16] DeAngelo, L. (1981). Auditor size and audit quality. Journal of Accounting and Economics. 3 (1): 113-127.

[17] Financial Accounting Standard Board (1980). Statement of Concepts No. 2: Qualitative characteristics of accounting information. Norwalk, CT: FASB.

[18] Francis, J., Olsson, R. and Schipper, K. (2004). Costs of capital and earnings attributes. The Accounting Review 79 (4): 967-1010.

[19] Ghosh, A. and Moon, D. (2005). Does auditor tenure impair audit quality? The Accounting Review 80 (2): 585-612.

[20] Giner, B., and Rees, W. (2001). On the asymmetric recognition of good and bad news in France, Germany and the United Kingdom. Journal of Business Finance \& Accounting 28 (9-10): 1333-1349.

[21] Givoly, D., and C. Hayn. (2000). The changing time series properties of earnings, cash flows and accruals: has financial reporting become more conservative? Journal of Accounting and Economics 29 (3): 287-320.

[22] Hamilton, J., Ruddock, C., Stokes, D., and Taylor, S. (2005). Audit partner rotation, earnings quality and earnings conservatism. Working paper, University of Technology, Sydney, and University of New South Wales.

[23] Jackson, A. B., Moldrich, M., \& Roebuck, P. (2008). Mandatory audit firm rotation and audit quality. Managerial Auditing Journal, 23, (5), 420-437.

[24] Jenkins, D., and Velury, U. (2008). Does auditor tenure influence the reporting of conservative earnings? Journal of Accounting and Public Policy, 27, 115-132.

[25] Kaplan, S., and Mauldin, E. (2008). Auditor rotation and the appearance of independence: Evidence from non-professional investors. Journal of Accounting and Public Policy, 27, 177192.

[26] Krishnan, G. (2003). Audit quality and the pricing of discretionary accruals. Auditing: A Journal of Practice and Theory 22 (1): 109-126.

[27] Krishnan, G. (2007). Did earnings conservatism increase for former Andersen clients? Journal of Accounting, Auditing and Finance 22 (2): 141-163.

[28] Myers, J., Myers, L. and Omer, T. (2003). Exploring the term of the auditor-client relationship and the quality of earnings: A case for mandatory auditor rotation? The Accounting Review 78 (3): 779-799.

[29] Pope, P. and Walker, M. (2002). Ex-ante and ex-post accounting conservatism, asset recognition, and asymmetric earnings timelines. Working Paper, Lancaster University.

[30] PricewaterhouseCoopers. (2002). Mandatory rotation of audit firms: will it improve audit quality? New York: PricewaterhouseCoopers. 
[31] Richardson, G. and Tinaikar, S. (2004). Accounting based valuation models: what have we learned? Accounting and Finance 44 (2): 223-255.

[32] Ryan, S. and Zarowin, P. (2003). Why has the contemporaneous linear returns earnings relation declined? The Accounting Review 78 (2): 523-553.
[33] Sinnett, W. (2004). Are there good reasons for auditor rotation? Financial Executive 20 (7): 29-32.

[34] Watts, R. (2003). Conservatism in accounting Part1: Explanations and implications. Accounting Horizons 17 (3): 207-221. 